\title{
E-SATISFACTION DAN E-TRUST BERPERAN DALAM MEMEDIASI PENGARUH E-SERVICE QUALITY TERHADAP E-LOYALTY PADA SITUS E-COMMERCE BLIBLI.COM
}

\author{
Ni Putu Indah Pradnyaswari ${ }^{1}$ \\ Ni Made Asti Aksari² \\ ${ }^{1,2}$ Fakultas Ekonomi Dan Bisnis Universitas Udayana (Unud), Bali, Indonesia \\ email: indah.pradnyaswari@yahoo.com
}

\begin{abstract}
ABSTRAK
Salah satu penentu keberhasilan perusahaan e-commerce terletak pada loyalitas konsumen online (e-loyalty) karena e-loyalty dapat mempengaruhi pembelian kembali dan rekomendasi terhadap produk perusahaan. Penting bagi perusahaan e-commerce untuk memberikan kualitas layanan elektronik (e-service quality) terbaik karena e-service quality dapat mempengaruhi kepuasan (satisfaction) dan kepercayaan (trust) konsumen sehingga konsumen tersebut berpotensi menjadi pelanggan yang loyal. Penelitian ini dilakukan pada situs e-commerce Blibli.com, dimana populasi dalam penelitian ini adalah masyarakat Provinsi Bali yang pernah melakukan pembelian pada situs Blibli.com. Teknik purposive sampling digunakan dalam penentuan jumlah sampel studi yang berjumlah 130 orang, dan data dianalisis menggunakan path analysis dan uji sobel. Hasil penelitian menunjukkan bahwa $e$-service quality berpengaruh secara positif dan signifikan terhadap $e$-satisfaction, $e$-trust dan $e$-loyalty. E-satisfaction dan $e$ trust berpengaruh secara positif dan signifikanterhadap e-loyalty."Hasil penelitian ini juga menunjukkan bahwa $e$-satisfaction dan $e$-trust mampu memediasi pengaruh $e$-service quality terhadap e-loyalty.
\end{abstract}

Kata kunci : e-loyalty, e-satisfaction, e-trust, e-service quality

\begin{abstract}
One of the success factor of an e-commerce company is its online consumer loyalty (eloyalty) because e-loyalty can influence repurchase decision and product recommendation. It is important for e-commerce companies to offer the best quality of electronic services (eservice quality) because e-service quality can influence consumers satisfaction and trust, which in turn resulting in customer loyalty. This research was conducted on an e-commerce site Blibli.com, with the people of Bali Province who have made purchases on Blibli.com as the study population. Purposive sampling technique was used to determine the sample size of 130 people used in this study, while path analysis and Sobel test was used to analyse the data. Research results show that e-service quality positively and significantly affect $e$ satisfaction, e-trust and e-loyalty. E-satisfaction and e-trust have a positive and significant effect on e-loyalty. Results of this study also show that e-satisfaction and e-trust can mediate the influence of e-service quality on e-loyalty.

Keywords : e-loyalty, e-satisfaction, e-trust, e-service quality
\end{abstract}




\section{PENDAHULUAN}

Saat ini e-commerce di Indonesia menjadi fenomena tren dan menjadi perhatian dari pelaku bisnis, hal ini berdasar dari data sensus BPS (Badan Pusat Statistik) tahun 2018 di Indonesia, peningkatan industri e-commerce mencapai 17 persen dengan total 26,2 juta jumlah usaha dalam kurun waktu 10 tahun terakhir (Wartaekonomi.co.id, 2019). Banyaknya e-commerce yang berkembang di Indonesia, membuat penyedia jasa layanan harus mampu memenuhi keinginan konsumen untuk menghadapi persaingan yang semakin ketat, dalam rangka menjaga kelangsungan hidup perusahaan.

Loyalitas konsumen bisa menjadi salah satu faktor utama untuk memperkuat daya saing pasar dan untuk memperkuat keunggulan kompetitif yang berkelanjutan, karena jauh lebih murah mempertahankan konsumen dari pada menarik konsumen yang baru (Choi \& Mai, 2018). Penting bagi perusahaan $e$ commerce untuk mengelola basis pelanggan yang loyal, karena hubungan pelanggan jangka panjang tidak hanya merupakan kontributor keuntungan utama, tetapi juga memiliki potensi tinggi untuk memperbesar volume penjualan di masa mendatang (Prisanti, dkk, 2017). E-loyalty merupakan suatu hal penting bagi bisnis online, yang menentukan sikap pelanggan tentang komitmennya untuk melakukan pemelian kembali serta merekomendasikan kepada calon konsumen baru. Berikut ini disajikan"data pengguna e-commerce di Indonesia.

Tabel 1.

Data Pengguna E-commerce Periode 2018 di Indonesia

\begin{tabular}{llcccc}
\hline No & E-commerce & \multicolumn{5}{c}{ Data Pengguna E-commerce Periode 2018 } \\
& & T W 1 & T W 2 & T W 3 & T W 4 \\
\hline 1 & Lazada & $117,6 \mathrm{jt} / \mathrm{bln}$ & $50 \mathrm{jt} / \mathrm{bln}$ & $36,4 \mathrm{jt} / \mathrm{bln}$ & $67,7 \mathrm{jt} / \mathrm{bln}$ \\
2 & BliBli & $45,9 \mathrm{jt} / \mathrm{bln}$ & $29 \mathrm{jt} / \mathrm{bln}$ & $31,3 \mathrm{jt} / \mathrm{bln}$ & $43,1 \mathrm{jt} / \mathrm{bln}$ \\
3 & JD.id & $13.2 \mathrm{jt} / \mathrm{bln}$ & $11.3 \mathrm{jt} / \mathrm{bln}$ & $11.4 \mathrm{jt} / \mathrm{bln}$ & $17 \mathrm{jt} / \mathrm{bln}$ \\
\hline
\end{tabular}

Sumber: Katadata.co.id, 2018.

Berdasarkan Tabel 1. layanan e-commerce milik lokal yaitu Blibli yang merupakan e-commerce dengan model bisnis B2C (Business to Consumer) dan merupakan satu-satunya e-commerce milik lokal dengan situs online shopping mall tidak mengalami peningkatan yang signifikan, beda halnya dengan layanan e-commerce yang belakangan hadir dari pada Blibli yaitu Lazada, dilihat dari triwulan 1 sampai triwulan 4 tahun 2018 mengalami peningkatan. Dengan hal ini berarti Blibli memiliki popularitas yang kurang dibandingkan pesaingnya yaitu Lazada.

Tercapainya tujuan organisasi secara efektif jika konsumen merasa puas dan berpotensi akan loyal terhadap produk atau jasa yang ditawarkan (Tjiptono \& Anastasia, 2019). E-satisfaction merupakan kepuasan konsumen dari pengalaman pembelian mereka sebelumnya, dua faktor utama dari pengalaman tersebut meliputi pelayanan dari situs online dan situs online itu sendiri (Santika \& Pramudana, 2018). E-satisfaction dapat disimpulkan suatu sikap pengguna dalam melakukan penilaian terhadap suatu situs yang berasal dari pengalaman pembelian sebelumnya yang akan menciptakan kepuasan pelanggan terhadap perusahaan 
perdagangan elektronik yang berasal dari faktor pelayanan dari situs online tersebut dan faktor situs online itu sendiri.

Mengenai cara membangun loyalitas konsumen, pemain bisnis khususnya bisnis online, harus sadar tentang pentingnya membangun kepercayaan konsumen, kepercayaan bisa didefinisikan sebagai kepercayaan diri atau kredibiltas, kredibilitas yang dimaksud adalah sejauh mana pemain bisnis bisa membuat konsumen percaya terhadap apa yang mereka tawarkan (Choi \& Mai, 2018). Dalam dunia bisnis elektronik, kepercayaan elektronik lebih dikenal dengan istilah e-trust. E-trust dapat dikatakan berkaitan dengan kepercayaan konsumen terhadap suatu situs untuk melakukan pembelian secara online (Susanto, 2018). Untuk meningkatkan kepercayaan pelanggan maka, penjual online harus memberikan informasi yang jelas, lengkap dan akurat sehingga pelanggan merasa bahwa toko online mengedepankan layanan online yang berkualitas, sehingga kepercayaan pelanggan terhadap situs tersebut meningkat.

E-service quality yang diberikan Blibli masih mendapat keluhan dari beberapa konsumen di tahun 2019. Berikut ini disajikan rangkuman keluhan konsumen Blibli.com.

Tabel 2.

Keluhan Pengguna Situs E-Commerce Blibli.com di Indonesia

\begin{tabular}{|c|c|c|c|}
\hline No & Nama & Keluhan & Sumber/Tahun \\
\hline 1 & Rudi Nopriadi & $\begin{array}{l}\text { Barang yang dipesan dan sudah dibayar } \\
\text { oleh konsumen belum dikonfirmasi oleh } \\
\text { pihak Blibli kepada Merchant (penjual) } \\
\text { sehingga barang tidak proses }\end{array}$ & $\begin{array}{l}\text { Mediakonsumen.com } \\
\text { (2017) }\end{array}$ \\
\hline 2 & Istamar & $\begin{array}{l}\text { Saya kecewa dengan layanan Blibli yang } \\
\text { berkaitan pada pengiriman dan layanan call } \\
\text { center. Sebabnya pengguna membeli } \\
\text { produk denga opsi pengiriman same day } \\
\text { yang merupakan layanan pengiriman dihari } \\
\text { yang sama terhitung } 6 \text { (enam) sampai } 8 \\
\text { (delapan) jam sejak pembayaran } \\
\text { terverifikasi dan diproses oleh merchant } \\
\text { partner, akan tetapi barang yang dipesan } \\
\text { tersebut belum dikirim sesuai dengan } \\
\text { ketentuan yang ada, sehingga pengguna } \\
\text { melakukan refund uang. }\end{array}$ & $\begin{array}{l}\text { Mediakonsumen.com } \\
\text { (2019) }\end{array}$ \\
\hline 3 & $\begin{array}{l}\text { Andraw Nur } \\
\text { Rahmad }\end{array}$ & $\begin{array}{l}\text { Hari ini saya betul-betul kecewa dengan } \\
\text { Blibli.com. Pelanggan membeli jam tangan, } \\
\text { namun barang yang diterima hanya berupa } \\
\text { kotak dengan kartu garansi tanpa adanya } \\
\text { jam tangan di dalam kotak tersebut }\end{array}$ & $\begin{array}{l}\text { Mediakonsumen.com } \\
\text { (2018) }\end{array}$ \\
\hline
\end{tabular}

Sumber: Kompas.com dan Mediakonsumen.com, 2019

Bagi bisnis online, komponen e-service quality adalah hal yang harus diciptakan untuk membentuk kepuasan pelanggan online (e-satisfaction) (Widiaputri, dkk, 2018). Berdasarkan penelitian yang dilakukan Tobagus, (2018) pada situs Tokopedia e-service quality berpengaruh terhadap e-satisafaction. Hubungan"ini ditemukan berpengaruh secara positif dan signifikan, dengan adanya e-service quality yang baik akan memberikan pengaruh yang signifikan 
terhadap e-satisfaction. Hal ini sejalan dengan penelitian yang dilakukan oleh Prisanti, dkk, (2017) pada Nasabah PT Bank Rakyat Indonesia (Persero) Tbk Kantor Cabang Pembantu Lawang, mengindikasikan hubungan yang positif antara e-service quality dengan e-satisfaction. Hasil penelitian Widiaputri, dkk, (2018) pada pelanggan Go-Ride menyatakan bahwa e-service quality berpengaruh signifikan terhadap e-satisfaction.

$\mathrm{H}_{1}$ : E-Service Quality berpengaruh positif dan signifikan terhadap ESastifaction.

Kepercayaan elektronik (e-trust) pengguna internet sangat bergantung pada kualitas layanan elektronik yang diberikan (e-service quality), kepercayaan ini sangat bergantung pada tingkat keamanan saat mereka melakukan transaksi (Hasanudin dkk., 2017). Konsumen online cenderung menginginkan bahwa penjual online bersedia dan mampu bereaksi untukkepentingan konsumen, mempertahankan kejujuran dalam transaksi, harus mampumenyediakan barang dan/atau jasa seperti yangdijanjikan, dan layanan elektronik yang baik, sehingga mereka nyaman melakukan transaksi (Prisanti dkk., 2017). Berdasarkan hasil penelitian yang dilakukan oleh Nurayni \& Widiartanto, (2019) menyatakan bahwa e-service quality berpengaruh signifikan, cukup kuat, dan positif terhadap $e$-trust pengguna application mobile KAI Access. Hal ini sejalan dengan penelitian yang dilakukan oleh Purnamasari, (2018) pada online retail bahwa e-service quality berpengaruh secara signifikan terhadap e-trust pada online retail, selain itu terdapat penelitian lain yang mendukung dilakukan oleh Ghane et al. (2011) pada e-banking di Iran"bahwa e-service quality memiliki pengaruh positif dan signifikan terhadap $e$-trust.

$\mathrm{H}_{2}$ : E-Service Quality berpengaruh positif dan signifikan terhadap E-Trust.

Kegiatan bisnis online yang sedang berkembang dengan pesat tentunya memerlukan keterlibatan pelayanan dari pemberi jasa semaksimal mungkin, agar nantinya mencegah pelanggan beralih ke pesaing, serta perusahaan harus mampu memahami cara membangun pelanggan dan kesetiaan di pasar online (e-loyalty) (Pudjarti, dkk, 2019). Konsekuensi dari pelayanan yang baik dilakukan oleh e-retailer adalah pelanggan akan bertahan pada pilihannya, serta memunculkan Perilaku seperti, tetap setia menggunakan situs tersebut dan membujuk orang lain untuk berbelanja di situs tersebut, perilaku ini berkaitan dengan loyalitas pelanggan (Riza \& Sutopo, 2017). Penelitian yang dilakukan oleh Purnamasari, (2018) menemukan e-service quality berpengaruh positif dan signifikan terhadap e-loyalty. Hal ini sejalan dengan hasil yang didapatkan dalam penelitian yang dilakukan oleh Santika \& Pramudana, (2018) menyatakan bahwa e-service quality berpengaruh positif dan signifikan terhadap e-loyalty. Semakin meningkat kualitas layanan online maka semakin meningkat loyalitas konsumen online. Hasil Penelitian tersebut juga didukung oleh Ambardy \& Candra, (2014), yang menyatakan bahwa e-service quality berpengaruh signifikan terhadap e-loyalty, maka dari itu perusahaan harus meningkatkan e-service quality agar dapat meningkatkan e-loyalty secara langsung.

$\mathrm{H}_{3}$ : E-Service Quality berpengaruh positif dan signifikan terhadap E-Loyalty.

E-satisfaction merupakan variabel fundamental atau variabel yang dianggap penting karena dapat membentuk e-loyalty (Purnamasari, 2018). Tinggi 
rendahnya kepuasan pelanggan elektronik terhadap suatu situs akan mempengaruhi besar atau kecilnya loyalitas pelanggan elektronik (Eid, 2011). Penelitian yang dilakukan oleh Wijiutami \& Octavia (2017) menyatakan bahwa e-satisfaction berpengaruh secara positif dan signifikan terhadap e-loyalty pada pelanggan e-commerce $\mathrm{C} 2 \mathrm{C}$ di kota Jakarta dan Bandung. Penelitian lain yang mendukung dilakukan oleh Eid (2011) pada e-commerce B2C di Saudi Arabia, menyatakan bahwa e-satisfaction berpengaruh terhadap e-customer loyalty. Hal ini sejalan dengan penelitian yang dilakukan oleh Melinda (2017) menyimpulkan bahwa $e$-satisfaction pelanggan berpengaruh secara signifikan terhadap $e$-loyalty pada Go-Jek.

$\mathrm{H}_{4}$ : E-Satisfaction berpengaruh positif dan signifikan terhadap E-Loyalty

E-trust dapat didefinisikan sebagai tingkat kepercayaan pelanggan terhadap saluran pertukaran online, kegagalan dalam online ritel disebabkan karena kurangnya kepercayaan konsumen terhadap saluran elektronik, maka dari itu $e$ trust dapat dianggap sebagai variabel yang dianggap penting dalam membentuk $e$ loyalty Ghane et al., 2011). Berdasarkan hasil penelitian yang dilakukan oleh Asih \& Pratomo, (2018)pada aktivitas belanja online yang dilakukan perempuan menyatakan bahwa $e$-trust memiliki pengaruh positif dan signifikan terhadap $e$ loyalty, hasil penelitian ini sejalan dengan penelitian yang dilakukan oleh Choi \& Mai, (2018) pada e-commerce B2C di Vietnam yang juga menyatakan bahwa $e$ trust berpengaruh positif dan signifikan terhadap e-loyalty. Penelitian yang dilakukan Hasanudin, Pujotomo \& Sriyanto, (2017) pada pengguna layanan $e$ commerce di Pulau Jawa menyatakan e-trust berpengaruh secara positif dan signifikan terhadap e-loyalty.

$\mathrm{H}_{5}:$ E-trust berpengaruh secara positif dan signifikan terhadap e-loyalty.

E-loyalty adalah dampak jangka panjang dari kepuasan pelanggan terhadap kinerja dari layanan suatu situs, pelanggan akan merasa puas terhadap layanan yang diberikan perusahaan jika mereka merasakan kualitas layanan yang mereka terima dapat memenuhi harapan (Jonathan, 2013). Penelitian yang dilakukan oleh Magdalena \& Jaolis (2018) menemukan bahwa e-service quality berpengaruh terhadap e-loyalty melalui e-satisfaction. Penelitian Santika \& Pramudana (2018) menyimpulkan bahwa secara signifikan e-satisfaction memediasi hubungan antara e-service quality terhadap e-loyalty. Penelitian yang dilakukan oleh Melinda, (2017) menyatakan bahwa e-service quality berpengaruh terhadap e-loyalty pelanggan GO-jek melalui e-satisfaction. Hal ini sejalan dengan penelitian yang dilakukan oleh Riza \& Sutopo (2017) pada pelanggan Lazada Indonesia menyatakan bahwa $e$-satisfaction mampu menjadi variabel intervening antara $e$ service quality terhadap e-loyalty.

$\mathrm{H}_{6}$ : E-Satisfaction memediasi pengaruh E-Service Quality terhadap E-Loyalty.

E-service quality yang baik adalah memberikan layanan yang baik sehingga konsumen merasa aman dan percaya dengan situs tersebut, sehingga dapat meningkatkan kepercayaan pelanggan karena kepercayaan merupakan faktor penting dalam interaksi bisnis-pelanggan sehingga akan menciptakan kesetiaan pelanggan terhadap suatu situs online (Berlianto, 2018). Teori ini mendukung penelitian yang dilakukan oleh Purnamasari, (2018) menunjukkan bahwa e-trust dapat memediasi pengaruh e-service quality terhadap e-loyalty. Hal ini sejalan 
dengan penelitian yang dilakukan oleh Nurayni \& Widiartanto, (2019) menyatakan bahwa terdapat pengaruh tidak langsung antara e-service quality terhadap e-loyalty melalui e-trust, dimana e-trust mampu menambah pengaruh variabel $e$-service quality dalam mempengaruhi $e$-loyalty.

$\mathrm{H}_{7}$ : E-Trust memediasi pengaruh E-Service Quality terhadap E-Loyalty .

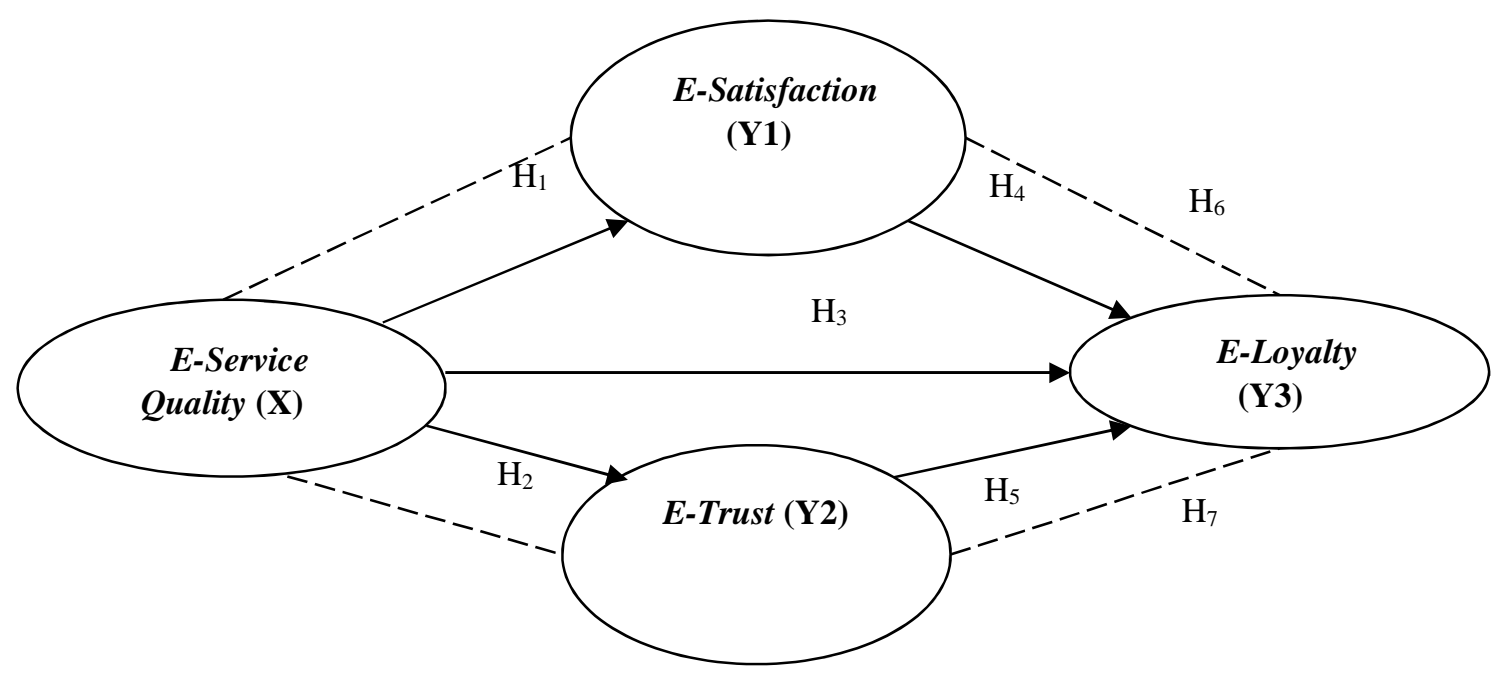

Gambar 1. Kerangka Konseptual Penelitian

Sumber: Data diolah, 2019

\section{METODE PENELITIAN}

Provinsi Bali menjadi lokasi dalam penelitian ini, dikarenakan berdasarkan data (Penyelenggara Jasa Internet Indonesia) APJII tahun 2018 di Provinsi Bali pengguna Internet bertambah sebesar 27,92 juta orang, atau meningkat sebesar 10,12\% dari tahun sebelumnya (cnbcindonesia, 2019). Populasi dari penelitian ini yaitu masyarakat Provinsi Bali yang sudah pernah menggunakan layanan Blibli.com. Responden penelitian ini yaitu 130 orang, yang mengacu pada ukuran 5 dikalikan jumlah indikator (Ferdinand, 2002). Penentuan sampel menggunakan teknik purposive sampling dengan pertimbangan tertentu, pertimbangan disini berdasarkan kriteria yaitu berdomisili di Provinsi Bali, sudah pernah menggunakan layanan situs e-commerce Blibli.com selama 6 bulan terakhir dan pendidikan minimal SMA. Metode pengumpulan data dengan menyebarkan kuesioner secara online melalui google form dan offline dengan cara membuat daftar pertanyaan tertulis.

Penelitian ini menggunakan teknik analisis jalur (path analysis) dengan tujuan untuk mengetahui pengaruh langsung maupun tidak langsung seperangkat variabel bebas (eksogen) terhadap variabel terikat (endogen) menggunakan software dengan program SPSS for windows. Pengujian hipotesis mediasi dilakukan dengan prosedur yang dikembangkan oleh Sobel (1982) dan dikenal dengan Uji Sobel (Sobel Test). Uji Sobel digunakan dengan menguji kekuatan 
pengaruh tidak langsung variabel $e$-service quality $(\mathrm{X})$ terhadap variabel $e$-loyalty $\left(\mathrm{Y}_{3}\right)$ melalui variabel e-satisfaction $\left(\mathrm{Y}_{1}\right)$ dan e-trust $\left(\mathrm{Y}_{2}\right)$.

\section{HASIL DAN PEMBAHASAN}

Jumlah responden dalam penelitian ini adalah 130 orang. Responden yang memberikan tanggapan pada kuesioner dari penelitian ini telah memenuhi kriteria yang ditetapkan, diantaranya yaitu: berpendidikan minimal SMA/SMK sederajat; berdomisili di Pulau Bali; dan sudah melakukan pembelian di e-commerce Blibli.com dalam kurun waktu 6 bulan terakhir. Deskripsi responden dalam penelitian ini disajikan pada Tabel 3. berikut:

Tabel 3.

Deskripsi Responden

\begin{tabular}{ccccc}
\hline No. & Karakteristik & Pilihan & $\begin{array}{c}\text { Jumlah responden } \\
\text { (orang) }\end{array}$ & Persentase (persen) \\
\hline 1 & Jenis Kelamin & Laki-Laki & 34 & 26,2 \\
& & Perempuan & 96 & 73,8 \\
2 & & Jumlah & 130 & 100 \\
& \multirow{4}{*}{ Umur } & $17-21 \mathrm{Thn}$ & 96 & 73,8 \\
& & $22-26 \mathrm{Thn}$ & 20 & 15,4 \\
& & $27-31 \mathrm{Thn}$ & 14 & 10,8 \\
3 & \multirow{4}{*}{ Pekerjaan } & 130 & 100 \\
& & Jumlah & 65 & 50,0 \\
& & Mahasiswa & 15 & 11,5 \\
& & Pegawai Swasta & 10 & 7,7 \\
& & PNS & 25 & 19,2 \\
& & Pelajar & 15 & 11,5 \\
& & Wiraswasta & 130 & 100 \\
\hline
\end{tabular}

Sumber: Data diolah, 2019

Tabel 3. menunjukkan bahwa jumlah responden yang berjenis kelamin perempuan sebanyak 96 orang atau 73,8\% dan jenis kelamin laki-laki sebanyak 34 orang atau 26,2\%. Hal ini menunjukkan bahwa mayoritas responden didominasi oleh perempuan. Responden dalam penelitian ini menunjukkan umur 17-21 tahun sebanyak 96 orang atau 73,8\%, umur 22-26 tahun sebanyak 20 orang atau sebesar $15,4 \%$ dan umur 27-31 tahun sebanyak 14 orang atau sebesar $10,8 \%$. Hal ini menunjukkan bahwa mayoritas responden lebih banyak pada umur 17-21 tahun. Jumlah responden berstatus mahasiswa sebanyak 65 orang atau sebesar 50,0\%, Pelajar sebanyak 25 orang atau sebesar 19,2\%, Pegawai Swasta sebanyak 15 orang atau sebesar $11,5 \%$, Wiraswasta sebanyak 15 orang atau sebesar $11,5 \%$ dan PNS sebanyak 10 orang atau sebesar 7,7\%. Ini berarti, responden dengan jumlah tertinggi berstatus mahasiswa sebanyak 65 orang.

Uji validitas bertujuan untuk memeriksa apakah kuesioner sebagai instrumen penelitian sudah tepat untuk mengukur indikator dalam penelitian sehingga dapat dikatakan valid. Apabila koefisien korelasi $\geq 0,30$ maka instrumen tersebut dapat dikatakan valid. Hasil uji validitas disajikan pada Tabel 4. 
Tabel 4.

Hasil Uji Validitas

\begin{tabular}{cccc}
\hline Variabel & Instrumen & Pearson Correlation & Keterangan \\
\hline & $\mathrm{X}_{1.1}$ & 0,596 & Valid \\
& $\mathrm{X}_{1.2}$ & 0,310 & Valid \\
& $\mathrm{X}_{1.3}$ & 0,617 & Valid \\
& $\mathrm{X}_{1.4}$ & 0,674 & Valid \\
& $\mathrm{X}_{1.5}$ & 0,655 & Valid \\
E-service quality $\left(\mathrm{X}_{1}\right)$ & $\mathrm{X}_{1.6}$ & 0,328 & Valid \\
& $\mathrm{X}_{1.7}$ & 0,341 & Valid \\
& $\mathrm{X}_{1.8}$ & 0,638 & Valid \\
& $\mathrm{X}_{1.9}$ & 0,481 & Valid \\
& $\mathrm{X}_{1.10}$ & 0,623 & Valid \\
& $\mathrm{X}_{1.11}$ & 0,445 & Valid \\
& $\mathrm{Y}_{1.1}$ & 0,661 & Valid \\
E-satisfaction $\left(\mathrm{Y}_{1}\right)$ & $\mathrm{Y}_{1.2}$ & 0,614 & Valid \\
& $\mathrm{Y}_{1.3}$ & 0,576 & Valid \\
& $\mathrm{Y}_{1.4}$ & 0,662 & Valid \\
& $\mathrm{Y}_{1.5}$ & 0,765 & Valid \\
& $\mathrm{Y}_{1.6}$ & 0,648 & Valid \\
& $\mathrm{Y}_{2.1}$ & 0,514 & Valid \\
& $\mathrm{Y}_{2.2}$ & 0,852 & Valid \\
E-trust $\left(\mathrm{Y}_{2}\right)$ & $\mathrm{Y}_{2.3}$ & 0,910 & Valid \\
& $\mathrm{Y}_{2.4}$ & 0,755 & Valid \\
& $\mathrm{Y}_{2.5}$ & 0,816 & Valid \\
& $\mathrm{Y}_{3.1}$ & 0,780 & Valid \\
& $\mathrm{Y}_{3.2}$ & 0,794 & Valid \\
& $\mathrm{Y}_{3.3}$ & 0,888 & Valid \\
E-loyalty $\left(\mathrm{Y}_{3}\right)$ & $\mathrm{Y}_{3.4}$ & 0,717 & Valid \\
& & &
\end{tabular}

Sumber: Data diolah, 2019

Hasil uji validitas instrumen penelitian yang disajikan dalam Tabel 4. menunjukkan bahwa seluruh indikato $\mathrm{r}$ pernyataan dalam variabel e-service quality, e-satisfaction, e-trust dan e-loyalty memiliki pearson correlation lebih besar dari 0,30 sehingga seluruh indikator tersebut telah memenuhi syarat validitas data.

Uji reliabilitas menunjukkan sejauh mana suatu alat pengukur dapat dipercaya atau dapat diandalkan. Apabila suatu alat pengukur dipakai dua kali untuk mengukur gejala yang sama dan hasil pengukuran yang diperoleh relatif konsisten, maka alat pengukur tersebut reliabel. Suatu instrumen dapat dikatakan reliabel apabila nilai Cronbach's Alpha $\geq 0,60$. Hasil pengujian reliabilitas instrumen dapat disajikan pada Tabel 5.

Tabel 5.

Hasil Uji Reliabilitas

\begin{tabular}{ccc}
\hline Variabel & Cronbach's Alpha & Keterangan \\
\hline E-service quality $(\mathrm{X})$ & 0,737 & Reliabel \\
E-satisfaction $\left(\mathrm{Y}_{1}\right)$ & 0,734 & Reliabel \\
E-trust $\left(\mathrm{Y}_{2}\right)$ & 0,829 & Reliabel \\
E-loyalty $\left(\mathrm{Y}_{3}\right)$ & 0,807 & Reliabel \\
\hline
\end{tabular}

Sumber: Data diolah, 2019 
Tabel 5. yang menunjukkan bahwa keempat instrumen penelitian yaitu variabel $e$-service quality, $e$-satisfaction, $e$-trust, dan $e$-loyalty memiliki koefisien Cronbach's Alpha lebih besar dari 0,60 sehingga pernyataan pada kuesioner tersebut reliabel.

Uji normalitas untuk mengetahui apakah residual dari model regresi yang dibuat berdistribusi normal atau tidak. Untuk menguji apakah data yang digunakan normal atau tidak dapat dilakukan dengan menggunakan uji Kolmogorov Smirnov. Apabila koesifien Asymp. Sig. (2-tailed) lebih besar dari 0,05 maka data tersebut dikatakan berdistribusi normal.

Tabel 6.

Hasil Uji Normalitas E-service quality Dengan E-satisfaction

\begin{tabular}{cc}
\hline & Unstandardized Residual \\
\hline $\mathrm{N}$ & 130 \\
Kolmogorov Smirnov & 0.503 \\
Asymp. Sig. (2-tailed) & 0.962 \\
\hline
\end{tabular}

Sumber: Data diolah, 2019

Tabel 6. menujukkan bahwa nilai Kolmogorov Smirnov $(K-S)$ sebesar 0,503 sedangkan nilai Asymp. Sig. (2-tailed) sebesar 0,962. Hasil tersebut mengindikasikan bahwa model persamaaan regresi $e$-service quality dengan $e$ satisfaction tersebut berdistribusi normal karena nilai Asymp. Sig. (2-tailed) sebesar 0,962 dimana lebih besar dari nilai alpha yaitu 0,05.

Tabel 7.

Hasil Uji Normalitas E-service quality Dengan E-trust

\begin{tabular}{cc}
\hline & Unstandardized Residual \\
\hline N & 130 \\
Kolmogorov Smirnov & 0.968 \\
Asymp. Sig. (2-tailed) & 0.306 \\
\hline Sumber: Data diolah, 2019
\end{tabular}

Tabel 8. menujukkan bahwa nilai Kolmogorov Smirnov $(K-S)$ sebesar 0,968 sedangkan nilai Asymp. Sig. (2-tailed) sebesar 0,306. Hasil tersebut mengindikasikan bahwa model persamaaan regresi e-service quality dengan $e$ trust tersebut berdistribusi normal karena nilai Asymp. Sig. (2-tailed) sebesar 0,306 dimana lebih besar dari nilai alpha yaitu 0,05 .

Tabel 8.

Hasil Uji Normalitas E-service quality, E-satisfaction dan E-trust Dengan Eloyalty

\begin{tabular}{cc}
\multicolumn{2}{c}{ loyalty } \\
\hline Unstandardized Residual \\
\hline Nolmogorov Smirnov & 130 \\
Asymp. Sig. (2-tailed) & 0.793 \\
\end{tabular}

Sumber: Data diolah, 2019 
Tabel 8. menujukkan bahwa nilai Kolmogorov Smirnov $(K-S)$ sebesar 0,793 sedangkan nilai Asymp. Sig. (2-tailed) sebesar 0,556. Hasil tersebut mengindikasikan bahwa model persamaaan regresi e-service quality, $e$ satisfaction dan e-trust dengan e-loyalty tersebut berdistribusi normal karena nilai Asymp. Sig. (2-tailed) sebesar 0,556 dimana lebih besar dari nilai alpha yaitu 0,05.

Uji multikolinieritas untuk menguji apakah pada model regresi ditemukan adanya korelasi antar variabel bebas. Adanya multikolinieritas dapat dilihat dari nilai tolerance atau variance inflaction factor (VIF). Jika nilai tolerance lebih dari $10 \%$ atau VIF kurang dari 10, maka dapat dikatakan tidak ada multikolinieritas.

Tabel 9.

Hasil Uji Multikolinieritas E-service quality Dengan E-satisfaction

\begin{tabular}{ccc}
\hline Variabel & Tolerance & VIF \\
\hline E-service quality & 1.000 & 1.000 \\
\hline
\end{tabular}

Sumber: Data diolah, 2019

Tabel 9. menunjukan nilai tolerance dan VIF dari variabel e-service quality. Nilai tersebut menunjukkan bahwa nilai tolerance lebih besar dari 10 persen dan nilai VIF lebih kecil dari 10 yang berarti model persamaan regresi e-service quality dengan e-satisfaction bebas dari multikolinieritas.

Tabel 10.

Hasil Uji Multikolinieritas E-service quality Dengan E-trust

\begin{tabular}{lcc}
\hline \multicolumn{1}{c}{ Variabel } & Tolerance & VIF \\
\hline E-service quality & 1.000 & 1.000 \\
\hline Sumber: Data diolah, 2019 & &
\end{tabular}

Tabel 10. menunjukkan nilai tolerance dan VIF dari variabel e-service quality. Nilai tersebut menunjukkan bahwa nilai tolerance lebih besar dari 10 persen dan nilai VIF lebih kecil dari 10 yang berarti model persamaan regresi $e$ service quality dengan $e$-trust bebas dari multikolinieritas.

Tabel 11.

Hasil Uji Multikolinieritas E-service quality, E-satisfaction dan E-trust Dengan E-loyalty

\begin{tabular}{lcc}
\hline \multicolumn{1}{c}{ Variabel } & Tolerance & VIF \\
\hline E-service quality & 0.819 & 1.221 \\
E-satisfaction & 0.803 & 1.245 \\
E-trust & 0.943 & 1.060 \\
\hline
\end{tabular}

Sumber: Data diolah, 2019

Tabel 11. menunjukkan nilai tolerance dan VIF dari variabel e-service quality, e-satisfaction dan e-trust. Nilai tersebut menunjukkan bahwa nilai tolerance untuk setiap variabel lebih besar dari 10 persen dan nilai VIF lebih kecil dari 10 yang berarti model persamaan regresi e-service quality, e-satisfaction dan $e$-trust dengan e-loyalty bebas dari multikolinieritas.

Uji Heteroskedastisitas untuk mengetahui apakah dalam model regresi terjadi ketidaksamaan varians dari residual satu pengamatan ke pengamatan yang 
lain yang dilakukan dengan uji Glejser. Jika tidak ada satu pun variabel bebas yang berpengaruh signifikan terhadap nilai absolut residual atau nilai signifikansinya di atas atau 0,05 maka tidak mengandung gejala heteroskedastisitas.

Tabel 12.

Hasil Uji Heteroskedastisitas $\boldsymbol{E}$-service quality Dengan $\boldsymbol{E}$-satisfaction

\begin{tabular}{lcc}
\hline \multicolumn{1}{c}{ Variabel } & T & Sig. \\
\hline E-service quality & -0.361 & 0.718 \\
\hline Sumber: Data diolah, 2019 & &
\end{tabular}

Tabel 12. menunjukkan bahwa nilai signifikansi dari variabel $e$-service quality sebesar 0,781 lebih besar dari 0,05 yang berarti tidak terdapat pengaruh antara variabel bebas terhadap absolut residual. Dengan demikian, model yang dibuat tidak mengandung gejala heteroskedastisitas.

Tabel 13.

Hasil Uji Heteroskedastisitas E-service quality Dengan E-trust

\begin{tabular}{lcc}
\hline \multicolumn{1}{c}{ Variabel } & T & Sig. \\
\hline E-service quality & 1.284 & 0.202 \\
\hline Sumber: & &
\end{tabular}

Sumber: Data diolah, 2019

Tabel 13. menunjukkan bahwa nilai signifikansi dari variabel e-service quality sebesar 0,202 lebih besar dari 0,05 yang berarti tidak terdapat pengaruh antara variabel bebas terhadap absolut residual. Dengan demikian, model yang dibuat tidak mengandung gejala heteroskedastisitas

Tabel 14.

Hasil Uji Heteroskedastisitas E-service quality, E-satisfaction dan E-trust Dengan E-loyalty

\begin{tabular}{lcc}
\hline \multicolumn{1}{c}{ Variabel } & T & Sig. \\
\hline E-service quality & 0.926 & 0.356 \\
E-satisfaction & 0.497 & 0.620 \\
E-trust & 1.383 & 0.169 \\
\hline
\end{tabular}

Sumber: Data diolah, 2019

Tabel 14. menunjukkan bahwa nilai signifikansi dari variabel e-service quality, e-satisfaction dan e-trust masing-masing sebesar 0,356;0,620;0,169. Nilai-nilai tersebut lebih besar dari 0,05 yang berarti tidak terdapat pengaruh antara variabel bebas terhadap absolut residual. Dengan demikian, model yang dibuat tidak mengandung gejala heteroskedastisitas.

Untuk mengetahui pengaruh e-service quality terhadap e-satisfaction digunakan alat analisis SPSS. Besarnya pengaruh e-service quality terhadap $e$ satisfaction dapat diketahui dari Tabel 14.

Tabel 15. menunjukkan pengaruh e-service quality terhadap e-satisfaction dapat diketahui dari besarnya nilai standardized beta $(\beta)$. Besarnya nilai standardized beta $\left(\beta_{1}\right)$ untuk variabel e-service quality adalah 0,417 sehingga dapat diketahui nilai jalur 1 (path 1) sebesar 0,417 dan signifikan pada 0,000 lebih 
kecil dari 0,05 (5\%) yang berarti e-service quality berpengaruh positif dan signifikan terhadap e-satisfaction.

Tabel 15.

Pengaruh E-service quality Terhadap E-satisfaction

\begin{tabular}{|c|c|c|c|c|c|}
\hline \multirow[t]{2}{*}{ Variabel } & \multicolumn{2}{|c|}{$\begin{array}{l}\text { Unstandardized } \\
\text { Coefficients }\end{array}$} & \multirow{2}{*}{$\begin{array}{c}\text { Standardized } \\
\text { Coefficients } \\
\text { B }\end{array}$} & \multirow[t]{2}{*}{$\mathbf{t}$} & \multirow[t]{2}{*}{ Sig } \\
\hline & B & Std. Error & & & \\
\hline $\begin{array}{l}\text { E-service quality } \\
\text { (Constant): } 6.670 \\
\text { R Square: } 0.174\end{array}$ & 0.288 & 0.056 & 0.417 & 5.188 & 0.000 \\
\hline
\end{tabular}

Sumber: Data diolah, 2019

Untuk menghitung e1 yang menunjukkan jumlah varian variabel $e$ satisfaction yang tidak dijelaskan oleh variabel e-service quality, maka digunakan rumus berikut:

$$
\sqrt{1-0,174}=0,909
$$

Untuk mengetahui pengaruh e-service quality terhadap e-trust digunakan alat analisis SPSS. Besarnya pengaruh e-service quality terhadap e-trust dapat diketahui dari Tabel 16. berikut:

Tabel 16.

Pengaruh E-service quality Terhadap E-trust

\begin{tabular}{lccccc}
\hline \multicolumn{1}{c}{ Variabel } & \multicolumn{2}{c}{$\begin{array}{c}\text { Unstandardized } \\
\text { Coefficients } \\
\text { Std. Error }\end{array}$} & $\begin{array}{c}\text { Standardized } \\
\text { Coefficients } \\
\text { B }\end{array}$ & t & Sig \\
\hline $\begin{array}{l}\text { E-service quality } \\
\text { (Constant): } 10.068\end{array}$ & 0.126 & 0.063 & 0.174 & 1.995 & 0.048 \\
R Square: 0.030 & & & & & \\
\hline Sumber: Data diolah, 2019 & & & & &
\end{tabular}

Tabel 16. menunjukkan pengaruh e-service quality terhadap e-trust dapat diketahui dari besarnya nilai standardized beta $(\beta)$. Besarnya nilai standardized beta $\left(\beta_{2}\right)$ untuk variabel e-service quality adalah 0,174 sehingga dapat diketahui nilai jalur 2 (path 2) sebesar 0,174 dan signifikan pada 0,048 lebih kecil dari 0,05 $(5 \%)$ yang berarti $e$-service quality berpengaruh positif dan signifikan terhadap $e$ trust.

Untuk menghitung e2 yang menunjukkan jumlah varian variabel e-trust yang tidak dijelaskan oleh variabel e-service quality, maka digunakan rumus berikut:

$$
\sqrt{1-0,030}=0,985
$$

Untuk mengetahui pengaruh e-service quality, e-satisfaction dan e-trust terhadap e-loyalty digunakan alat analisis SPSS. Besarnya pengaruh e-service quality, e-satisfaction dan e-trust terhadap e-loyalty dapat diketahui dari Tabel 17.

Untuk menghitung e3 yang menunjukkan jumlah varian variabel $e$-loyalty yang tidak dijelaskan oleh variabel $e$-service quality, e-satisfaction dan e-trust, maka digunakan rumus berikut: $\sqrt{1-0,209}=0,889$. 
Tabel 17.

Pengaruh E-service quality, E-satisfaction Dan E-trust Terhadap E-loyalty

\begin{tabular}{|c|c|c|c|c|c|}
\hline \multirow[t]{2}{*}{ Variabel } & \multicolumn{2}{|c|}{$\begin{array}{l}\text { Unstandardized } \\
\text { Coefficients }\end{array}$} & \multirow{2}{*}{$\begin{array}{c}\text { Standardized } \\
\text { Coefficients } \\
\text { B }\end{array}$} & \multirow[t]{2}{*}{$\mathbf{t}$} & \multirow[t]{2}{*}{ Sig } \\
\hline & B & Std. Error & & & \\
\hline E-service quality & 0.112 & 0.051 & 0.191 & 2.186 & 0.031 \\
\hline E-satisfaction & 0.204 & 0.075 & 0.240 & 2.714 & 0.008 \\
\hline $\begin{array}{l}\text { E-trust } \\
\text { (Constant): } 1.152 \\
\text { R Square: } 0.209\end{array}$ & 0.164 & 0.066 & 0.203 & 2.484 & 0.014 \\
\hline
\end{tabular}

Sumber: Data diolah, 2019

Berdasarkan hasil analisis jalur (path analysis) dapat diketahui besarnya pengaruh langsung antar variabel. Pengaruh langsung antar variabel disajikan pada Tabel 18. berikut:

Tabel 18.

Pengaruh Langsung E-service quality $(\mathrm{X})$, E-satisfaction $\left(\mathrm{Y}_{1}\right)$, E-trust $\left(\mathrm{Y}_{2}\right)$ dan E-loyalty $\left(\mathbf{Y}_{3}\right)$

\begin{tabular}{lc}
\hline \multicolumn{1}{c}{ Pengaruh Variabel } & Pengaruh Langsung \\
\hline E-service quality $(\mathrm{X}) \rightarrow$ E-satisfaction $\left(\mathrm{Y}_{1}\right)$ & 0,417 \\
E-service quality $(\mathrm{X}) \rightarrow$ E-trust $\left(\mathrm{Y}_{2}\right)$ & 0,174 \\
E-service q uality $(\mathrm{X}) \rightarrow$ E-loyalty $\left(\mathrm{Y}_{3}\right)$ & 0,191 \\
E-satisfaction $\left(\mathrm{Y}_{1}\right) \rightarrow$ E-loyalty $\left(\mathrm{Y}_{3}\right)$ & 0,240 \\
E-trust $\left(\mathrm{Y}_{2}\right) \rightarrow$ E-loyalty $\left(\mathrm{Y}_{3}\right)$ & 0,203
\end{tabular}

Sumber: Data diolah, 2019

Tabel 19.

Pengaruh Langsung, Pengaruh Tidak Langsung dan Pengaruh Total $E$ service quality $(\mathrm{X})$, E-satisfaction $\left(\mathrm{Y}_{1}\right)$, E-trust $\left(\mathrm{Y}_{2}\right)$ dan $\quad$ E-loyalty $\left(\mathrm{Y}_{3}\right)$

\begin{tabular}{lccc}
\hline \multicolumn{1}{c}{ Pengaruh Variabel } & $\begin{array}{c}\text { Pengaruh } \\
\text { Langsung }\end{array}$ & $\begin{array}{c}\text { Pengaruh } \\
\text { Tidak } \\
\text { langsung }\end{array}$ & $\begin{array}{c}\text { Pengaruh } \\
\text { Total }\end{array}$ \\
\hline E-service quality $(\mathrm{X}) \rightarrow$ E-satisfaction $\left(\mathrm{Y}_{1}\right)$ & 0,417 & - & - \\
E-service quality $(\mathrm{X}) \rightarrow$ E-trust $\left(\mathrm{Y}_{2}\right)$ & 0,174 & - & - \\
E-service quality $(\mathrm{X}) \rightarrow$ E-loyalty $\left(\mathrm{Y}_{3}\right)$ & 0,191 & - & - \\
E-satisfaction $\left(\mathrm{Y}_{1}\right) \rightarrow$ E-loyalty $\left(\mathrm{Y}_{3}\right)$ & 0,240 & 0,100 & 0,340 \\
E-trust $\left(\mathrm{Y}_{2}\right) \rightarrow$ E-loyalty $\left(\mathrm{Y}_{3}\right)$ & 0,203 & 0,035 & 0,238 \\
\hline
\end{tabular}

Sumber: Data diolah, 2019

Data tersebut menunjukkan bahwa e-service quality berpengaruh langsung terhadap e-loyalty sebesar 19,1 persen, dengan dimediasi e-satisfaction maka didapatkan pengaruh tidak langsung sebesar 10,0 persen, dan pengaruh total sebesar 34,0 persen. Hasil tersebut menunjukkan bahwa e-satisfaction memediasi pengaruh e-service quality terhadap e-loyalty secara parsial. Hasil Tabel juga menunjukkan $e$-service quality dimediasi $e$-trust, maka didapatkan pengaruh tidak langsung sebesar 3,5 persen, dan pengaruh total sebesar 23,8 persen. Hasil tersebut menunjukkan bahwa e-trust memediasi pengaruh $e$-service quality terhadap $e$-loyalty secara parsial.

Dari nilai $\mathrm{e}_{1}, \mathrm{e}_{2}$ dan $\mathrm{e}_{3}$ yang telah diketahui maka koefisien determinasi total dapat dihitung sebagai berikut: 


$$
\begin{aligned}
\mathrm{R}^{2} \mathrm{~m} & =1-\left(\mathrm{e}_{1}\right)^{2}\left(\mathrm{e}_{2}\right)^{2}\left(\mathrm{e}_{3}\right)^{2} \ldots \ldots \ldots \ldots \ldots \\
& =1-(0,909)^{2}(0,985)^{2}(0,889)^{2} \\
& =0,366
\end{aligned}
$$

Koefisien determinasi total sebesar 0,366 artinya sebesar 36,6 persen variasi variabel $e$-loyalty dipengaruhi oleh variabel $e$-service quality, $e$-satisfaction dan $e$ trust, sedangkan sisanya sebesar 63,4 persen dijelaskan oleh faktor lain yang tidak dimasukkan ke dalam model.

Uji Sobel merupakan teknik analisis untuk menguji signifikansi dan pengaruh tidak langsung antara variabel bebas (endogen) dengan variabel terikat (eksogen) yang dimediasi oleh variabel mediasi (intervene). Uji Sobel dihitung dengan menggunakan aplikasi Microsoft Excel 2017. Nilai koefisien z jika lebih besar dari 1,96, maka variabel variabel mediasi (intervene) dalam penelitian ini dinilai secara signifikan mampu memediasi pengaruh variabel bebas (eksogen) terhadap variabel terikat (endogen).

Peran $e$-satisfaction memediasi $e$-service quality dengan $e$-loyalty dengan uji Sobel dihitung dengan persamaan sebagai berikut:

$$
Z=\frac{a}{\sqrt{b^{2} S^{2}+a^{2} S^{2}+S^{2} S^{2}}}
$$

Keterangan:

$$
\begin{aligned}
& \mathrm{a}=0,417 \\
& \mathrm{~S}_{\mathrm{a}}=0,056 \\
& \mathrm{~b}=0,240 \\
& \mathrm{~S}_{\mathrm{b}}=0,075 \\
& \mathrm{z}=\frac{\mathrm{a}}{\sqrt{\mathrm{b}^{2} \mathrm{~S}^{2}+\mathrm{a}^{2} \mathrm{~S}^{2}+\mathrm{S}^{2} \mathrm{~S}^{2}}}\left(\frac{(0,4)(0,2 \quad)}{\mathrm{z}}=\frac{}{\sqrt{(0,2)^{2}(0,0 \quad)^{2}+(0,4)^{2}(0,0 \quad)^{2}+(0,0 \quad)^{2}(0,0 \quad)^{2}}}\right. \\
& \mathrm{z}=2,9400
\end{aligned}
$$

Hasil Uji Sobel yang telah dihitung menunjukkan bahwa nilai koefisien $\mathrm{z}$ adalah 2,9400>1,96 sehingga $\mathrm{H}_{0}$ ditolak dan $\mathrm{H}_{1}$ diterima. Hasil tersebut mengartikan bahwa e-satisfaction sebagai variabel mediasi dinilai secara positif dan signifikan mampu memediasi pengaruh $e$-service quality terhadap e-loyalty.

Peran $e$-trust memediasi e-service quality dengan e-loyalty dengan uji Sobel dihitung dengan persamaan sebagai berikut:

Keterangan:

$$
\mathrm{Z}=\frac{\mathrm{a}}{\sqrt{\mathrm{b}^{2} \mathrm{~S}^{2}+\mathrm{a}^{2} \mathrm{~S}^{2}+\mathrm{S}^{2} \mathrm{~S}^{2}}}
$$

$$
\begin{aligned}
& \mathrm{a}=0,174 \\
& \mathrm{~S}_{\mathrm{a}}=0,063 \\
& \mathrm{~b}=0,203 \\
& \mathrm{~S}_{\mathrm{b}}=0,066 \\
& \mathrm{z}=\frac{\mathrm{a}}{\sqrt{\mathrm{b}^{2} \mathrm{~S}^{2}+\mathrm{a}^{2} \mathrm{~S}^{2}+\mathrm{S}^{2} \mathrm{~S}^{2}}} \\
& \mathrm{Z}=\frac{(0,1 \quad)(0,2 \quad)}{\sqrt{(0,2 \quad)^{2}(0,0 \quad)^{2}+(0,1 \quad)^{2}(0,0 \quad)^{2}+(0,0 \quad)^{2}(0,0 \quad)^{2}}} \\
& \mathrm{z}=2,0550
\end{aligned}
$$


Hasil Uji Sobel yang telah dihitung menunjukkan bahwa nilai koefisien $\mathrm{z}$ adalah 2,0550>1,96 sehingga $\mathrm{H}_{0}$ ditolak dan $\mathrm{H}_{1}$ diterima. Hasil tersebut mengartikan bahwa e-trust sebagai variabel mediasi dinilai secara positif dan signifikan mampu memediasi pengaruh $e$-service quality terhadap $e$-loyalty.

Berdasarkan hasil penelitian e-service quality berpengaruh positif dan signifikan terhadap e-satisfaction. Ini menunjukkan, semakin baik e-service quality yang diberikan Blibli.com akan meningkatkan e-satisfaction pengguna layanan Blibli.com. E-satisfaction akan terbentuk pada saat melakukan pembelian atau setelah melakukan pembelian, e-service quality merupakan suatu hal yang harus dipertimbangkan agar konsumen merasa puas (Prisanti dkk., 2017) .

Hasil penelitian ini sejalan dengan hasil penelitian yang dilakukan Tobagus, (2018) pada pengguna situs Tokopedia di Surabaya dan Widiaputri dkk. (2018) pada pelanggan Go-Ride di Malang yang menyatakan bahwa e-service quality berpengaruh terhadap e-satisfaction. Metode pengumpulan data pada penelitian ini serupa dengan penelitian sebelumnya yaitu melalui penyebaran kuesioner secara online dengan teknik analisis data yang digunakan yaitu path analysis dan mayoritas responden yang menjawab dibawah 30 tahun. Hasil penelitian yang sama dilakukan oleh Prisanti dkk. (2017) pada industri yang berbeda yakni pada Nasabah PT Bank Rakyat Indonesia di Malang.

Berdasarkan hasil analisis menunjukkan bahwa e-service quality berpengaruh secara positif dan signifikan terhadap e-trust. Ini berarti, semakin baik e-service quality yang diberikan oleh situs e-commerce Blibli.com akan meningkatkan e-trust pengguna layanan e-commerce Blibli.com. Perusahaan diharapkan mampu menjaga kualitas service aplikasi sehingga dengan terjaganya kestabilan service dapat meningkatkan kepercayaan konsumen terhadap perusahaan dan mampu memenuhi kebu tuhan konsumen (Nurayni \& Widiartanto, (2019).

Hasil penelitian ini sejalan dengan penelitian yang dilakukan oleh Purnamasari, (2018) pada konsumen belanja online di Bandung, melalui penyebaran kuesioner secara online yang didominasi oleh perempuan dan mayoritas responden mahasiswa dengan alat analisis SEM-PLS (Partial Least Square), yang menunjukkan bahwa e-service quality berpengaruh secara signifikan terhadap e-trust. Hasil penelitian yang sama pada industri berbeda yang dilakukan oleh (Ghane et al., 2011) pada E-banking di Iran dengan alat analisis SEM-PLS (Partial Least Square) yang menunjukkan bahwa e-service quality berpengaruh positif dan signifikan terhadap e-trust, Nurayni \& Widiartanto, (2019) pada pengguna aplikasi mobile KAI acces di Semarang dengan alat analisis path analysis menyatakan bahwa e-service quality berpengaruh signifikan, cukup kuat, dan positif terhadap $e$-trust, dengan mayoritas responden yang menjawab lebih banyak perempuan dibandingkan laki-laki dan didominasi umur 17-21 tahun.

Hasil penelitian ini menunjukkan bahwa e-service quality berpengaruh positif dan signifikan terhadap e-loyalty. Ini berarti, semakin baik e-service quality yang diberikan, maka pelanggan akan loyal terhadap e-commerce Blibli.com. 
Hasil penelitian ini mendukung penelitian tentang e-commerce yang dilakukan oleh Ambardy \& Candra, (2014) pada konsumen Maskool.in di Jakarta Selatan, Purnamasari (2018) pada konsumen belanja online di Bandung, Santika \& Pramudana (2018) pada pengguna situs online travel di Bali yang menyatakan bahwa e-service quality berpengaruh positif terhadap e-loyalty. Penelitian ini serupa dengan penelitian terdahulu yang terletak pada karakteristik responden dengan mayoritas mahasiswa lebih banyak dibandingkan pekerjaan lainnya dan alat analisis yang digunakan juga sama yaitu path analysis.

Berdasarkan hasil analisis menyatakan bahwa e-satisfaction berpengaruh secara positif dan signifikan terhadap e-loyalty. Ini berarti, semakin meningkat kepuasan elektronik (e-satisfaction) maka akan meningkatkan loyalitas elektronik (e-loyalty) terhadap e-commerce Blibli.com, apabila kepuasan telah tercipta maka akan memberikan berbagai manfaat salah satunya dapat membentuk loyalitas konsumen dengan adanya pembelian berulang di situs tersebut dan rekomendasi dari mulut ke mulut (Melinda, 2017).

Hasil penelitian ini mendukung hasil penelitian sebelumnya mengenai e-commerce yang dilakukan oleh Eid, (2011) pada e-commerce b2c di Saudi Arabia yang menggunakan alat analisis SEM-PLS (Partial Least Square), Melinda, (2017) pada customer Go-Ride di Surabaya dengan alat analisis SEMPLS (Partial Least Square), Wijiutami \& Octavia, (2017) pada pelanggan ecommerce $\mathrm{c} 2 \mathrm{c}$ di Jakarta dan Bandung dengan menggunakan path analysis menyatakan bahwa $e$-satisfaction berpengaruh positif dan signifikan terhadap $e$ loyalty. Hasil karakteristik responden pada penelitian ini serupa dengan penelitian sebelumnya yaitu mayoritas responden berusia di bawah 30 tahun dan didominasi oleh mahasiswa.

Hasil penelitian ini menunjukkan e-trust berpengaruh positif dan signifikan terhadap $e$-loyalty. Ini berarti, semakin meningkat $e$-trust pengguna layanan maka akan menciptakan e-loyalty pengguna layanan e-commerce Blibli.com, dengan meningkatnya kepercayaan pelanggan terhadap suatu situs online maka pelanggan akan menggunakan atau berbelanja kembali di situs online Blibli.com (Choi \& Mai, 2018)

Hasil dari penelitian ini mendukung penelitian tentang e-commerce yang dilakukan oleh Asih \& Pratomo (2018) pada belanja online yang dilakukan perempuan, Choi \& Mai (2018) pada e-commerce b2c di Vietnam dan Hasanudin dkk. (2017) pada pengguna layanan e-commerce di Pulau Jawa menyatakan bahwa e-trust memiliki pengaruh positif dan signifikan terhadap e-loyalty. Data karakteristik responden pada penelitian ini sama dengan penelitian sebelumnya yaitu didominasi oleh usia di bawah 30 tahun dan mayoritas responden yang menjawab adalah pelajar.

Hasil uji Sobel menunjukkan bahwa $e$-satisfaction sebagai variabel mediasi dinilai secara positif dan signifikan mampu memediasi pengaruh e-service quality terhadap e-loyalty. E-service quality yang baik akan menimbulkan kepuasan kepada pelanggan terciptanya kepuasan pelanggan dapat memberikan beberapa manfaat, di antaranya terciptanya loyalitas pelanggan terhadap suatu produk tertentu dan membentuk suatu rekomendasi dari mulut ke mulut yang menguntungkan bagi perusahaan (Melinda, 2017) 
Hasil penelitian ini sejalan dengan hasil penelitian yang dilakukan oleh Melinda (2017)pada pelanggan Go-Ride di Surabaya dengan alat analisis SEMPLS (Partial Least Square), Riza \& Sutopo (2017) pada pelanggan Lazada Indonesia di Semarang dengan alat analisis regresi linier berganda, Magdalena \& Jaolis, (2018) pada pelanggan Blibli.com di Surabaya dengan teknik analisis data PLS (Partial Least Square), Santika \& Pramudana (2018) pada pengguna online travel di Bali dengan teknik analisis data path analysis menyatakan bahwa $e$ service quality memiliki pengaruh tak langsung terhadap loyalitas konsumen melalui kepuasan konsumen yang dapat diartikan e-service quality berpengaruh terhadap e-loyalty melalui e-satisfaction, dengan adanya kualitas layanan elektronik yang baik maka akan menciptakan kepuasan konsumen secara online, sehingga konsumen akan loyal terhadap situs tersebut. Karakteristik responden pada penelitian ini sama dengan penelitian sebelumnya yaitu didominasi oleh mahasiswa berusia di bawah 30 tahun dengan metode pengumpulan data melalui survei kuesioner online dan offline.

Hasil uji Sobel menunjukkan bahwa e-trust sebagai variabel mediasi dinilai secara positif dan signifikan mampu memediasi pengaruh e-service quality terhadap e-loyalty. E-service quality mampu menjadi perantara bagi e-loyalty untuk menimbulkan $e$-trust. Dengan memberikan kualitas layanan elektronik yang baik, maka akan meningkatkan kepercayaan pengguna situs e-commerce Blibli.com yang nantinya akan berdampak pada loyalitas elektronik (Choi \& Mai, 2018).

Hasil penelitian ini sejalan dengan hasil penelitian yang dilakukan oleh Purnamasari, (2018) pada konsumen belanja online di Bandung dengan teknik analisis data SEM-PLS (Partial Least Square) menunjukkan bahwa e-trust dapat memediasi pengaruh e-service quality terhadap e-loyalty. Penelitian ini serupa dengan penelitian sebelumnya yaitu metode pengumpulan data melalui survei online dan jumlah responden perempuan lebih banyak dibandingkan laki-laki yang didominasi oleh mahasiswa. Hasil penelitian yang sama juga dilakukan pada industri yang berbeda oleh Nurayni \& Widiartanto (2019) pada pengguna aplikasi mobile KAI acess di Semarang dengan teknik analisis data path analysis menunjukkan bahwa terdapat pengaruh tidak langsung antara e-service quality terhadap e-loyalty melalui $e$-trust, dimana $e$-trust mampu menambah pengaruh variabel $e$-service quality dalam mempengaruhi $e$-loyalty. Karakteristik responden pada penelitian ini dengan penelitian sebelumnya didominasi oleh perempuan dan mayoritas umur yang menjawab dari 17-21 tahun

Berdasarkan model yang dikembangakan dalam penelitian ini dapat memperkuat konsep-konsep teoritis dan memberikan dukungan secara empiris terhadap penelitian terdahulu. Implikasi teoritis dapat memperkuat penelitian sebelumnya bahwa e-service quality dapat meningkatkan $e$-satisfaction dan $e$ trust sehingga akan mempengaruhi e-loyalty pengguna situs e-commerce Blibli.com. Dengan adanya persamaan hasil temuan dengan penelitian sebelumnya membuktikan bahwa perbedaan wilayah yang diteliti dan objek penelitian yang berbeda dapat menghasilkan hasil yang sama. Sehingga model ini dapat digeneralisasikan jika digunakan pada produk atau industri jasa yang berkaitan dengan kegiatan elektronik. 
Berdasarkan hasil penelitian yang telah diuraikan di atas, maka e-service quality menjadi faktor utama dalam mempengaruhi perilaku konsumen terutama kepuasan elektronik (e-satisfaction) dan kepercayaan elektronik (e-trust). Oleh karena itu sangat penting bagi manager pemasaran atau para pengambil keputusan untuk memperhatikan persepsi positif konsumen dari indikator $e$-service quality. Kesebelas indikator tersebut merupakan faktor yang berpengaruh untuk membentuk $e$-satisfaction dan $e$-trust, yang pada akhirnya dapat menciptakan $e$ loyalty.

\section{SIMPULAN}

E-service quality berpengaruh positif dan signifikan terhadap e-satisfaction. Hal ini berarti jika Blibli.com mampu memberikan kualitas layanan elektronik (e-service quality) yang baik, maka akan meningkatkan kepuasan elektronik (e-satisfaction) bagi pengguna situs Blibli.com di Provinsi Bali. E-service quality berpengaruh positif dan signifikan terhadap e-trust. Hasil ini berarti bahwa apabila semakin baik e-service quality yang ditawarkan oleh situs e-commerce Blibli.com maka semakin meningkatkan e-trust pengguna layanan dalam melakukan pembelian pada situs tersebut di Provinsi Bali. E-service quality berpengaruh positif dan signifikan terhadap e-loyalty. Hasil ini berarti bahwa semakin baik e-service quality yang diberikan maka meningkatkan e-loyalty pengguna layanan situs e-commerce Blibli.com di Provinsi Bali.

E-satisfaction berpengaruh positif dan signifikan terhadap e-loyalty. Hasil ini menunjukkan bahwa semakin puas pengguna terhadap layanan elektronik (e-satisfaction) semakin meningkat loyalitas elektronik (e-loyalty) pengguna layanan situs e-commerce Blibli.com di Provinsi Bali. E-trust berpengaruh positif dan signifikan terhadap e-loyalty. Hasil ini menunjukkan bahwa semakin percaya pengguna terhadap layanan elektronik (e-trust) maka semakin meningkat loyalitas elektronik (e-loyalty) pengguna layanan situs e-commerce Blibli.com di Provinsi Bali. E-satisfaction secara positif dan signifikan berperan dalam memediasi pengaruh e-service quality terhadap e-loyalty. Ini berarti, semakin baik kualitas layanan yang diberikan oleh situs $e$-commerce Blibli.com akan meningkatkan rasa puas di benak konsumen yang mengakibatkan pengguna situs e-commerce Blibli.com di Provinsi Bali akan loyal. E-trust secara positif dan signifikan berperan dalam memediasi pengaruh e-service quality terhadap e-loyalty. Ini berarti, semakin baik kualitas layanan yang diberikan oleh situs e-commerce Blibli.com akan meningkatkan kepercayaan konsumen secara online untuk berbelanja di situs tersebut yang pada akhirnya akan menciptakan loyalitas elektronik bagi pengguna situs e-commerce Blibli.com di Provinsi Bali.

Berdasarkan hasil penelitian ini, untuk dapat meningkatkan e-satisfaction dan $e$-trust melalui $e$-service quality yang nantinya akan meningkatkan $e$-loyalty pengguna Blibli.com adalah Blibli.com hendaknya dapat memperbaiki kualitas layanan yang berkaitan dengan layanan customer service, contohnya memberikan respon yang cepat untuk menanggapi keluhan konsumen. Blibli.com mampu menawarkan fasilitas yang menarik pengguna, sehingga pengguna merasa bahagia berbelanja di Blibli.com, misalnya dengan memberikan fasilitas untuk 
membandingkan harga suatu produk dengan produk lainnya yang sejenis. Pihak Blibli.com sebaiknya lebih memperhatikan sistem keamanan website agar konsumen bersedia memberikan data pribadi mereka, misalnya dengan penjelasan lengkap mengenai penggunaan data pribadi konsumen oleh pihak perusahaan dan tidak akan membagikan identitas mereka ke orang lain. Pihak Blibli.com sebaiknya lebih memperhatikan sistem pelayanan yang diberikan dengan memberikan saran ketika pembeli akan memilih suatu produk yang dibutuhkan sehingga pembeli akan merasa terbantu dengan adanya saran yang diberikan oleh pihak Blibli.com.

Bagi peneliti selanjutnya yang ingin melakukan penelitian dengan tema yang sama disarankan untuk dapat menambahkan variabel lain yang dapat membentuk e-loyalty seperti e-crm (electronic customer relationship), e-wom (electronic word of mouth), kualitas website, serta dapat melakukan penelitian pada umur di atas 30 tahun.

\section{REFERENSI}

Ambardy, I. P., \& Candra, S. (2014).Analisis Pengaruh E-Service Quality Terhadap E-Satisfaction Dan Dampaknya Pada E-Loyaty. Jurnal Ilmu Administrasi Bisnis, (27), 1-11.

Asih, R.R.D ., \& Pratomo, L. D. (2018).Peran Mediasi E-Satisfaction Dan ETrust Terhadap E-Loyalty. Jurnal Manajemen Dan Pemasaran Jasa, 11(1), $125-144$.

Berlianto, M. P. (2018).Pengaruh Kualitas Layanan-E, Kepuasan-E, Dan Kepercayaan-E Terhadap Kesetiaan-E Pada Gojek. Journal Of Management and Business Review, 1-28.

Choi, Y., \& Mai, D. Q. (2018). The Sustainable Role of the E-Trust in the B2C E-Commerce of Vietnam. Sustainability (Switzerland). https://doi.org/10.3390/su10010291

Cnbcindonesia. (2018). Bisnis e-commerce: peluang besar tapi persaingan kian sengit. Diunduh dari cnbcindonesia.com website: https://www.cnbcindonesia.com/tech/20181123162712-39-43447/bisnisecommerce-peluang-besar-tapi-persaingan-kian-sengit

Eid, M. I. (2011).Determinants Of E-Commerce Customer Satisfaction, Trust, And Loyalty In Saudi Arabia. 78-93. Journal of Electronic Commerce Research, 12(1): 78-93

Ferdinand. (2002). Metode Penelitian Manajemen: Pedoman Penelitian Untuk Skripsi, Tesis, dan Desertasi Ilmu Manajemen. Semarang: Universitas Diponegoro

Ghane, S., Fathian, M., \& Gholamian, M.R. (2011).Full Relationship Among ESatisfaction, E- Trust, E-Service Quality,And E-Loyalty: The Case Of Iran E-Banking. Journal of Theoretical and Applied Information Technology, 
$33(1)$.

Hasanudin, M.P., \& Sriyanto. (2017).Pengaruh Dimensi E-Servqual, Satisfaction Dan Trust Terhadap Loyalitas Pengguna Layanan E-Commerce Indonesia (Studi Kasus: Pengguna Layanan e-commerce di Pulau Jawa). e-journal undip, 6(3), 1-12.

Istamar. (2019). Kecewa dengan layanan Blibli.com. Diunduh dari mediakonsumen.com https://www.google.co.id/amp/s/mediakonsumen.com/2019/04/02/suratpembaca/kecewa-dengan-layanan-blibli-com/amp

Jonathan, H. (2013).Analisis Pengaruh E-Service Quality terhadap Customer Satisfaction yang Berdampak pada Customer Loyalty PT. Bayu Buana Travel Tbk. The Winners, 14(2), 104. https://doi.org/10.21512/tw.v14i2.650

Magdalena, A., \& Jaolis, F. (2018).Analisis Antara E-Service Quality, ESatisfaction, dan E-Loyalty Dalam Konteks E-Commerce Blibli. Jurnal Strategi Pemasaran, 5(2), 1-11.

Melinda. (2017).Pengaruh E-Service Quality Terhadap E-Loyalty Pelanggan GoJek Melalui E-Satisfaction Pada Kategori Go-Ride. Agora, 5(1).

Nopriadi, R. (2017). Diunduh dari mediakonsumen.com : https://www.google.co.id/amp/s/mediakonsumen.com.2017/12/04/suratpembaca/blibli-com-tidak-profesional/amp

Nurayni, D., \& Widiartono. (2019). Pengaruh E-Service Quality, E-Satisfaction Dan E-Trust Terhadap Customer Loyality Pengguna Aplikasi Mobile KAI Access (Studi pada pengguna Aplikasi Mobile KAI Acces Semarang). Jurnal Ilmu Administrasi Bisnis. 8 (1):1-7

Prisanti, D.M., Suyadi, I., \& Arifin, Z. (2017).Pengaruh E-Service Quality Dan ETrus Terhadap E-Customer Satisfaction Serta Implikasinya Terhadap Ecustomer Loyalty. Journal Of Business Studies, 2(1), 19-38.

Pudjarti, S., Nurchayati, N., \& Dwi Putranti, H. R. (2019). Penguatan Kepuasan Model Hubungan E-Service Quality Dan E-Loyalty Pada Konsumen Go-Jek Dan Grab. Sosiohumaniora, 21(3), 237-246. https://doi.org/10.24198/sosiohumaniora.v21i3.21491

Purnamasari, D. (2018).The Roles of E-Service Quality , E-Trust , and ESatisfaction on Online Retail Loyalty. Industrial Research Workshop and National Seminar, 1(2), 634-641.

Rahmad, A. N. (2018). Kecewa QC pengiriman Blibli.com, barang yang diterima tidak sesuai dengan pesanan. Diunduh dari: mediakonsumen.com: https://www.google.co.id/amp/s/mediakonsumen.com/2018/07/22/suratpembaca/kecewa/qc-pengiriman-blibli.com-barang-yang-diterima-tidaksesaui-pesanan/amp 
Riza, S., \& Sutopo. (2017).Analisis Pengaruh E-Service Quality, Kualitas Informasi Dan Persepsi Kemudahan Terhadap E-Loyalty dengan ESatisfaction sebagai Variabel Intervening (Studi Pada Pelanggan Lazada Indonesia). Diponegoro Journal Of Management, 6, 1-13.

Santika, I.W., \& Pramudana., K. A. S. (2018).Peran Mediasi E-Satisfaction Pada Pengaruh E-Service Quality Terhadap E-Loyalty Situs Online Travel di Bali. Jurnal Inovasi Bisnis Dan Manajemen Indonesia, 1(BPS 2015), 278289.

Susanto, S. A. (2018). Pengaruh E-Satisfaction \& E-Trust Konsumen Hotel Terhadap Online Repurchase Intention di Traveloka. Journal of Chemical Information and Modeling, 53(9), 1689-1699. https://doi.org/10.1017/CBO9781107415324.004

Tjiptono, F., dan Diana, A. (2019). Kepuasan Pelanggan Konsep,Pengukuran, dan Strategi (Edisi Pertama). Yogyakarta: CV. Andi Offset

Tobagus, A. (2018). Pengaruh E-Service Quality Terhadap E-Satisfaction Pada Pengguna Di Situs Tokopedia. Jurnal AGORA, 6(1), 1-10.

Wartaekonomi.co.id.(2019). Pertumbuhan e-commerce pesat di Indonesia. Diunduh dari Wartaekonomi.co.id Website https://m.wartaekonomi.co.id/berita216302/pertumbuhan-e-commercepesat-di-indonesia.html

Widiaputri, Y. S., Suharyono., \& Bafadhal, A.S (2018). Pengaruh E-Service Quality Terhadap Perceived Value Dan E- Customer Satisfaction (Survei pada Pelanggan Go-Ride yang Menggunakan Mobile Application Go-Jek di Kota Malang). Jurnal Administrasi Bisnis, 61(1), 1-10.

Wijiutami, S.S., \& Octavia, D. (2017). Pengaruh E-Service Quality Terhadap ESatisfaction Serta Dampaknya Pada E-Loyalty Pelanggan E-Commerce C2c Di Kota Jakarta Dan Bandung. E-Proceeding of Management, 4(3), 22122220. 